\title{
Translation of the Extended Addictive Features Section of the Ottawa Self-injury Inventory Version 3.1 in German
}

\author{
Christopher Alan Lewis (iD ${ }^{1,}{ }^{*}$, Sarah Davis (iD) ${ }^{2}$, Dagmar A. S. Corry (iD ${ }^{3}$ and Sarah Demmrich (iD ${ }^{4}$ \\ ${ }^{1}$ Department of Psychology and Therapeutic Studies, Leeds Trinity University, Leeds, England, UK \\ ${ }^{2}$ Division of Psychology and Mental Health, University of Manchester, Manchester, England, UK \\ ${ }^{3}$ Department of Psychology, Glyndwr University, Wrexham, Wales, UK \\ ${ }^{4}$ Cluster of Excellence Religion and Politics, University of Munster, Munster, Germany \\ "Corresponding author: Department of Psychology and Therapeutic Studies, Leeds Trinity University, Leeds, England, UK. Email: c.lewis@leedstrinity.ac.uk \\ Received 2021 August 24; Accepted 2021 November 18
}

Keywords: Addiction, Self-harm, Non-suicidal Self-injury, German

\section{Dear Editor,}

Recently, Plener et al. (1) have reviewed the literature on non-suicidal self-injury (self-harm) in adolescents, with a particular focus on the German context. In addition, some research on non-suicidal self-injury, conducted among German-speaking participants in Austria, Germany, and Switzerland (2-4), has operationalised self-harm using the German translation $(2,5)$ of the Ottawa Self-injury Inventory version 3.1 (OSI 3.1) $(6,7)$. Recently four newly developed items have been added to the Addictive Features section of the OSI 3.1 (8).

In addition to the German translation $(2,5)$, the OSI 3.1 $(6,7)$ has been translated into several languages, including Mandarin Chinese (9), French (7, 10), Hebrew (11), Turkish (12), Hungarian (13), Russian (14), and Albanian (15). Given this, these four newly developed items in the addictive features section (8) have now been translated into Hungarian (16), Turkish (17), Russian (18), and Urdu (19). Therefore, the aim was to complement the German translation of the OSI $3.1(2,5)$ by converting these newly developed items (8) into German.

The four newly-developed items (8) were translated from English into German and back-translated by two experienced bi-lingual Austrian and German academics with expertise in clinical and health psychology. No issues were raised by the translators. Both the English and German translations of the four newly-developed items are presented in Table 1.

If this extended version of the OSI 3.1 is found to be reliable and valid this will enable self-harm research among German speakers, particularly on self-harm addiction.

\section{Footnotes}

Authors' Contribution: Christopher Alan Lewis and Sarah Davis jointly designed and prepared the manuscript. Dagmar A. S. Corry and Sarah Demmrich provided German translation and provided input into the writing of the manuscript.

Conflict of Interests: The authors declared that there were no conflicts of interest.

Ethical Approval: Not applicable.

Funding/Support: This research was not sponsored by any individual or organisation.

\section{References}

1. Plener PL, Kaess M, Schmahl C, Pollak S, Fegert JM, Brown RC. Nonsuicidal self-injury in adolescents. Dtsch Arztebl Int. 2018;115(3):23-30. doi: 10.3238/arztebl.2018.0023. [PubMed: 29366448]. [PubMed Central: PMC5787659].

2. Plener PL, Libal G, Keller F, Fegert JM, Muehlenkamp JJ. An international comparison of adolescent non-suicidal self-injury (NSSI) and suicide attempts: Germany and the USA. Psychol Med. 2009;39(9):1549-58. doi: 10.1017/S0033291708005114. [PubMed: 19171079].

3. Plener PL, Straub J, Kapusta ND, Fegert JM, Sprober N. [Assessment of suicidal ideation in adolescents: Comparison of two instruments]. Prax Kinderpsychol Kinderpsychiatr. 2012;61(1):4-15. doi: 10.13109/prkk.2012.61.1.4. [PubMed: 22400375].

4. Plener PL, Fischer CJ, In-Albon T, Rollett B, Nixon MK, Groschwitz RC, et al. Adolescent non-suicidal self-injury (NSSI) in German-speaking countries: Comparing prevalence rates from three community samples. Soc Psychiatry Psychiatr Epidemiol. 2013;48(9):1439-45. doi: 10.1007/s00127-012-0645-z. [PubMed: 23292435].

5. Plener PL. Selbstverletzende und suizidale Verhaltensweisen in einer deutschen Schulstichprobe. Universität Ulm; 2011. 
6. Cloutier PF, Nixon MK. The Ottawa Self-injury Inventory: A preliminary evaluation. Abstracts to the 12th International Congress European Society for Child and Adolescent Psychiatry. European Child \& Adolescent Psychiatry; 2003. p. 1-94.

7. Martin J, Cloutier PF, Levesque C, Bureau JF, Lafontaine MF, Nixon MK. Psychometric properties of the functions and Addictive Features scales of the Ottawa Self-Injury Inventory: A preliminary investigation using a university sample. Psychol Assess. 2013;25(3):1013-8. doi: 10.1037/a0032575. [PubMed: 23647037].

8. Davis S, Lewis CA. Re: The Ottawa Self-injury Inventory Version 3.1: Suggestions for revision to the Addictive Features section. Int JMent Health Addict. 2017;16(3):711-3. doi: 10.1007/s11469-017-9831-2.

9. Fang ZHANG, Wen-hong CHENG, Ze-ping XIAO. Study on reliability and validity of Chinese version of Ottawa Self-injury Inventory. $J$ Shanghai Jiao Univ. 2015;35(3):460.

10. Levesque C, Lafontaine MF, Bureau JF, Cloutier P, Dandurand C. The influence of romantic attachment and intimate partner violence on non-suicidal self-injury in young adults. $J$ Youth Adolesc. 2010;39(5):474-83. doi: 10.1007/s10964-009-9471-3. [PubMed: 19885722].

11. Rodav O, Levy S, Hamdan S. Clinical characteristics and functions of non-suicide self-injury in youth. Eur Psychiatry. 2014;29(8):503-8. doi: 10.1016/j.eurpsy.2014.02.008. [PubMed: 24725924].

12. Çuhadaroğlu FÇ, Zeki A. Non-suicidal self-injury among Turkish adolescents. Vilnius, Lithuania. World Psychiatry Association Inter Zonal Congress; 2017.
13. Csorba J, Ferencz E, Steiner P, Nemeth A. Characteristics of Hungarian adolescents with self-injurious behavior. Results of a pilot study. Eur Psychiatry. 2006;21(suppl 1):156-7.

14. Lewis CA, Davis S, Khukhrin M, Svetlana G, Filimonova E, Safina Z. Cross-language validity of the Russian translation of the Ottawa SelfInjury Inventory version 3.1 among a sample of bilingual Russian students. Eur Psychiatry. 2019;56:373.

15. Alikaj V, Xhura I, Spaho E, Hashorva A, Skendi V. Characteristics and functions of self injury in a sample of adolescents attending Child and Adolescent Psychiatry Clinic in Tirana. Anthropol Res Stud. 2016;1(6):55-62.

16. Lewis CA, Davis S, Martos T, Csuka SI. Hungarian translation of four additional items for the Addictive Features section of the Ottawa Selfinjury Inventory version 3.1. Psychiatr Danub. 2018;30(2):235-6. doi: 10.1145/3230977.3231016.

17. Lewis CA, Davis S, Ok U, Yanik M. Turkish translation of four additional items for the Addictive Features section of the Ottawa Selfinjury Inventory version 3.1. Turk Psikiyatri. 2018;29(4):295-6. doi: 10.1145/3230977.3231016.

18. Lewis CA, Davis S, Khukhrin M, Svetlana G, Filimonova E, Safina Z. Cross-language validity of the Russian translation of the Ottawa Selfinjury Inventory version 3.1 among a sample of bilingual Russian students. Eur Psychiatry. 2019;56:373.

19. Lewis CA, Davis S, Sohail T, Khawaja AO. Urdu translation of the Ottawa Self-injury Inventory version 3.1. Asia Pac Psychiatry. 2019;11(3). e12359. doi: 10.1111/appy.12359. [PubMed: 31059190]. 
Table 1. English and German Versions of the Four Additional Items for the Addictive Features Section of the Ottawa Self-injury Inventory Version 3.1.

"Never a Reason"

"Always a Reason"

(Niemals ein Grund) (Immer ein Grund)

8. Self-harming behaviours seem to stabilise your

0

1

2

3

4

Laune zu stabilisieren.)

9. When ceasing self-harm behaviour, you feel strong emotion(s) such as tense, anxious, morose, guilty, irate,

0

1

2

temperamental, agitated, or irritable. (Beim Aufhören

der Selbstverletzung fühlst Du starke Emotionen, wie

Angespanntheit, Ängstlichkeit, Mürrischkeit,

Schuldgefühle, Wut, Launenhaftigkeit, Erregtheit, oder

Gereiztheit.)

10. There is the urge to self-harm and the self-inflicted

pain creates a "high". (Es besteht der Drang zur

Selbstverletzung und der selbstverschuldete Schmerz

verursacht ein "Hoch".)

11. You lose control of the behaviour. (Du verlierst die

Kontrolle über das Verhalten.)

0

0

2

3 